\title{
Effects of Proton Pump Inhibitor for Laryngopharyngeal Reflux and Comorbid Chronic Rhinosinusitis
}

\author{
Hahn Jin Jung, Ji Hwan Kim, Min Hyuck Kang, and Dong Wook Lee \\ Department of Otorhinolaryngology-Head and Neck Surgery, Chungbuk National University College of Medicine, \\ Chungbuk National University Hospital, Cheongju, Korea
}

\section{양성자 펌프 억제제가 인후두 역류증과 동반된 만성 비부비동염에 미치는 영향}

정한진 · 김지환 · 강민혁 · 이동욱

충북대학교 의과대학 충북대학교병원 이비인후과학교실

Received July 23, 2018

Revised September 6, 2018

Accepted September 17, 2018

Address for correspondence

Dong Wook Lee, MD

Department of Otorhinolaryngology-

Head and Neck Surgery,

Chungbuk National University

College of Medicine,

Chungbuk National University

Hospital, 776 1sunhwan-ro,

Seowon-gu, Cheongju 28644, Korea

Tel +82-43-269-6157

Fax $+82-43-265-6157$

E-mail dwlee@chungbuk.ac.kr
Background and Objectives Laryngopharyngeal reflux (LPR) is a prevalent condition with an increasing incidence, and several recent studies have reported the association of LPR with chronic rhinosinusitis (CRS). In this study, we studied the effect of proton-pump inhibitors (PPIs) on symptom improvement for LPR and comorbid CRS.

Subjects and Method Enrolled in the study from January 2017 to December 2017 were 164 patients ( 54 male, 110 female, mean age 48.8 years) who were diagnosed as LPR by reflux symptom index (RSI) or reflux finding scores (RFS) and comorbid CRS. Sino-Nasal Outcome Test (SNOT)-20 and Lund-Kennedy endoscopic scores were evaluated for CRS severity. The study group was divided into PPI treatment group (Ilaprazole $20 \mathrm{mg}$, once a day for 8 weeks) and non-treatment group. The RSI, RFS, SNOT-20, and Lund-Kennedy endoscopic scores were repeated at the end of treatment.

Results Ninety-two patients were prescribed PPI and 72 patients were not. Initial RSI, RFS, SNOT-20, and Lund-Kennedy score did not differ between the two groups. RSI and RFS decreased significantly after eight weeks of PPI medication ( $p=0.002$ and $p<0.001$, respectively) In the non-treatment group, only RFS showed statistically significant decrease. SNOT-20 and Lund-Kennedy endoscopic scores decreased significantly in the treatment group $(p=0.005$ and $p<0.001$, respectively) compared to the non-treatment group.

Conclusion The results of our study suggest that PPI treatment for 8 weeks was effective in reducing signs and symptoms of both LPR and CRS.

Korean J Otorhinolaryngol-Head Neck Surg 2019;62(3):165-70

Key Words Chronic rhinosinusitis · Proton pump inhibitor · Reflux finding score

Reflux symptom index $\cdot$ Sino-Nasal Outcome Test-20.
서 론

인후두 역류증(laryngopharyngeal reflux, LPR)은 구역이 나 구토 없이 위의 내용물이 인후두로 역류하는 현상으로 인

This is an Open Access article distributed under the terms of the Creative Commons Attribution Non-Commercial License (https://creativecommons.org/licenses/by-nc/4.0) which permits unrestricted non-commercial use, distribution, and reproduction in any medium, provided the original work is properly cited.
후두 이물감, 애성 및 만성 기침과 인후통, 음성 장애 등의 증 상이 나타나게 된다. ${ }^{1)}$ 인후두 역류증의 유병률은 이비인후과 외래 환자의 10 20\%로 보고되어 상당히 높은 것으로 알려 져 있으며, 후두나 성대 질환이 있는 환자의 $50 \%$ 가 인후두 역 류증을 가지고 있다는 보고도 있다.,3) 인후두 역류증은 위산 과 펩신에 반복적인 노출로 인한 방어기전의 파괴가 발병 원 인으로 생각되고 있으나, 그 병태 생리와 분자 수준에서의 기 
전은 밝혀져 있지 않다. ${ }^{4)}$ 1990년대 이후, 인후두 역류증이 여 러 상기도 질환의 발병 및 증상 악화의 원인 인자가 된다는 보고들이 있으며, 발성 장애, 후두 경련, 성대 육아종, 후두 종양, 만성 중이염, 비염, 천식, 그리고 만성 비부비동염 등과 의 다양한 연관성이 연구되고 있다. ${ }^{5-7)}$

만성 비부비동염 환자의 $88 \%$ 에서 인후두 역류증이 동반되 어 있다는 보고가 있으며, ${ }^{6,8)}$ 펩신 등의 소화 효소가 만성 비 부비동염 환자의 비분비물에서 검출이 된 바도 있다. ${ }^{7)}$ 본 연구 에서는 인후두 역류증과 동반된 만성 비부비동염이 진단된 환 자를 대상으로 양성자 펌프 억제제 약물 치료의 효과에 대해 알아보고자 하였다.

\section{대상 및 방법}

2017년 1월부터 12월까지 본원 이비인후과를 방문하여 인 후두 역류 관련 증상을 호소한 환자 중 인후두 내시경 및 역 류 증상 설문 조사를 시행하여 인후두 역류증으로 진단받은 환자를 대상으로 하였다. 이 중 만성 비부비동염이 동반된 것 으로 추가 확인된 환자로 최종 164 명을 대상으로 하였다. 18 세 이상의 성인 환자, 과거력 상 비흡연자, 전문적으로 음성을 사용하지 않는 일반인을 대상으로 하였으며, 2 개월간의 기간 동안 생활 습관 및 식습관 교정 순응도가 높고, 치료 전후로 검사와 설문지에 모두 응한 환자를 대상으로 하였다. 알레르 기 비염, 천식, 낭포성 섬유증, 그리고 심한 전신질환이 있는 환자는 제외하였으며, 내원 한 달 이내에 인후두 역류증 관 련 약물 복용력이 없는 경우로 대상 환자를 제한하였다. 본 연구는 전향적 무작위 배정 연구로 진행되었으며, 본원의 임 상시험윤리위원회(Institutional Review Board) 심의를 승인 받았다(IRB No. 2017-04-004).

인후두 역류증의 진단은 잦은 목청소, 인후두 이물감, 만성 기침 및 애성 등의 증상이 3 개월 이상 있었던 병력과 함께,
인후두 역류증의 증상과 소견을 체계적으로 점수화하기 위하 여 흔히 사용되고 있는 인후두 역류 증상 점수(reflux symptom index, RSI)와 인후두 내시경 검사를 통한 인후두 역류 소견 점수(reflux finding score, RFS)를 평가하였다. ${ }^{9-11)} \mathrm{RSI}$ 는 Belafsky 등 ${ }^{10)}$ 이 제안한 설문지로, 9 가지 증상이 생활에 지 장을 주는 정도에 따라 0 5점으로 평가하여 총점 0에서 45점 으로 평가하였으며, 13점 이상일 때 인후두 역류증으로 진단 하였다(Table 1). RFS는 인후두 내시경 소견에서 Belafsky 등 ${ }^{11)}$ 이 제안한 8 개 항목(성문하 부종, 성대 부종, 후두실 폐쇄, 미만성 후두 부종, 후두 발적, 후연합부 점막 비후, 끈적한 후 두 내 분비물, 육아종)에 따라 0 26점으로 평가하였으며, 본 연구에서는 7점 이상일 때 인후두 역류증으로 진단하였다 (Table 2). 3개월 이상의 인후두 역류 증상 병력이 확인되고, $\mathrm{RSI}$ 가 13점 이상이거나 RFS가 7점 이상인 경우에 LPR로 최 종 진단하였다. 구역반사가 심하여 RFS를 제대로 측정할 수 없어 굴곡 내시경을 시행한 경우는 연구 대상에서 제외하였다.

만성 비부비동염의 진단은 European position paper on rhinosinusitis and nasal polyps 2012 $2^{12)}$ 의 진단기준에 따라, 12 주 이상 지속된 코막힘, 비루 등의 병력 확인 및 비내시경검사 를 시행하여 진단하였다. 모든 환자는 컴퓨터단층촬영을 촬 영하였으며 부비동 개구연합과 부비동 점막의 변화를 확인 하였다. 만성 비부비동염에서의 주관적인 증상에 대해 SinoNasal Outcome Test(SNOT)-20 설문지로 평가하였으며, 객관 적인 비내시경 소견은 Lund-Kennedy 내시경 점수로 평가하 였다. SNOT-20은 코 증상에 의한 건강과 관련된 삶의 질을 측정하는 도구로, 비과적 증상영역, 귀/안면 증상영역, 수면 영역 및 심리영역에 대해 각 단계별로 0 5점으로 점수화하여 20 문항에 대한 총점으로 점수화하게 된다. ${ }^{13)}$ Lund-Kennedy 내시경 점수는 비분비물, 부종 및 비용종에 대해 $0,1,2$ 점으 로 점수를 배정하여 합산하였다. ${ }^{14)}$

대상 환자 모두에게 인후두 역류증에 대한 생활 습관 및

Table 1. Reflux symptom index

\begin{tabular}{|c|c|c|c|c|c|c|}
\hline \multirow{2}{*}{$\begin{array}{c}\text { 지난 한 달간 환자분께 다음의 증상들이 얼마나 문제가 되었습니까? } \\
\text { 쉰 목소리가 난다(거칠거나, 고르지 않은 목소리가 난다, 목소리에 문제가 있다). }\end{array}$} & \multicolumn{6}{|c|}{$\begin{array}{c}0=\text { 전혀 문제 되지 않았다. } \\
5=\text { 아주 심하여서 심각한 지장을 준다. }\end{array}$} \\
\hline & 0 & 1 & 2 & 3 & 4 & 5 \\
\hline 목청을 가다듬는다(하루에 네 번이상 목청을 가다듬는다, 헛기침을 한다). & 0 & 1 & 2 & 3 & 4 & 5 \\
\hline 후비루가 있다(코에서 목구멍으로 점액이나 분비물이 넘어간다). & 0 & 1 & 2 & 3 & 4 & 5 \\
\hline 음식물을 삼키기 어렵다(연하곤란). & 0 & 1 & 2 & 3 & 4 & 5 \\
\hline 식사 후나 누우면 기침이 나온다. & 0 & 1 & 2 & 3 & 4 & 5 \\
\hline 숨쉬기 힘들거나 가끔 사래가 든다. & 0 & 1 & 2 & 3 & 4 & 5 \\
\hline 성가시거나 문제가 되는 기침이 난다. & 0 & 1 & 2 & 3 & 4 & 5 \\
\hline 목구멍에 이물감을 느낀다(목구멍에 덩어리가 걸려있는 느낌이 든다). & 0 & 1 & 2 & 3 & 4 & 5 \\
\hline 가슴이 쓰리거나/아프거나, 소화가 안되거나, 위산이 넘어오는 것을 느낀다. & 0 & 1 & 2 & 3 & 4 & 5 \\
\hline
\end{tabular}

A reflux symptom index $\geq 13$ can be indicative of laryngopharyngeal reflux 
식습관 개선을 교육하였다. 이후 환자는 무작위하게 두 그룹 으로 나누어, 양성자 펌프 억제제 비투여군과 투여군으로 분 류하였다. 비투여군은 약물 치료 없이 생활 및 식습관 교정만 을 시행하였고, 투여군에게는 하루 한차례 아침식사 30분 전 일라프라졸 $20 \mathrm{mg}$ (Noltec ${ }^{\circledR}$ 2정)을 8주간 경구 복용하도록 하였다. 확인된 만성 부비동염에 대해서는 추가로 다른 약물 을 처방하지 않았다. 환자는 8주간의 치료 종료 후 RSI와 SNOT-20 설문지를 시행하였으며, 동일한 검사자가 일관되게 RFS와 Lund-Kennedy 내시경 점수를 평가하였다. 검사자의 선입견을 최소화하도록 치료 전 RFS와 Lund-Kennedy 내시 경 점수 결과를 진료기록과는 별도로 기록하여 기존의 점수 를 알지 못한 상태에서 치료 후 검사를 시행하도록 하였다.

비투여군과 투여군의 비교는 SPSS version 12.0(SPSS

\section{Table 2. Reflux finding score}

\begin{tabular}{|c|c|}
\hline \multicolumn{2}{|c|}{ Reflux finding scores } \\
\hline \multirow[t]{2}{*}{ Pseudosulcus (infraglottic edema) } & 0 absent \\
\hline & 2 present \\
\hline \multirow[t]{2}{*}{ Ventricular obliteration } & 2 partial \\
\hline & 4 complete \\
\hline \multirow[t]{2}{*}{ Erythema/hyperemia } & 2 only of arytenoids \\
\hline & 4 diffuse \\
\hline \multirow[t]{4}{*}{ Vocal fold edema } & 1 mild \\
\hline & 2 moderate \\
\hline & 3 severe \\
\hline & 4 polypoid \\
\hline \multirow[t]{4}{*}{ Diffuse laryngeal edema } & 1 mild \\
\hline & 2 moderate \\
\hline & 3 severe \\
\hline & 4 obstructive \\
\hline \multirow[t]{4}{*}{ Posterior commissure hypertrophy } & 1 mild \\
\hline & 2 moderate \\
\hline & 3 severe \\
\hline & 4 obstructive \\
\hline \multirow[t]{2}{*}{ Granuloma/granulation } & 0 absent \\
\hline & 2 present \\
\hline \multirow[t]{2}{*}{ Thick endolaryngeal mucus } & 0 absent \\
\hline & 2 present \\
\hline
\end{tabular}

A reflux finding score $\geq 7$ in the appropriate situation is strongly suggestive of laryngopharyngeal reflux
Inc., Chicago, IL, USA)을 이용하여 두 군 간에 치료 전 나이, 성별, RSI, RFS, SNOT-20, 그리고 Lund-Kennedy 내시경 점수에 차이가 있는지 독립표본 $\mathrm{t}$ 검정을 통해 비교하였으며, 각 군에서 치료 전과 치료 후의 호전 여부에 대해 대응표본 $\mathrm{t}$ 검정을 통해 비교하였다. $p$-value가 0.05 이하일 때 통계적으 로 유의하다고 정의하였다.

\section{결 과}

전체 164 명의 대상 환자는 여자 110 명, 남자 54 명으로 여자 가 많았다. 평균 나이 48.8세(18 78세)였으며, 무작위적으로 양성자 펌프 억제제 비투여군 72명, 투여군 92명으로 배정되 었다. 두 군 간에 성비와 연령 분포는 통계적으로 유의한 차이 가 없었다(Table 3).

총 164 명의 환자에서 치료 전에 평가한 RSI는 평균 $20.5 \pm$ 6.6점(10 41)이었다. 개별 항목 중 '목구멍에 이물감'이 평균 3.5점으로 가장 높았고, '목청을 가다듬는다', '기침', 그리고 '쉰

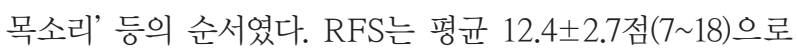
후두 발적이 2.6점이었고 성대 부종이 2.0점이었다. 치료 전 평

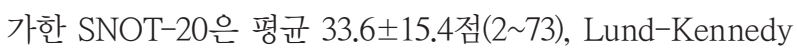

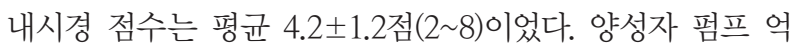
제제 비투여군과 투여군 간에 각각의 점수 항목에서 통계적 으로 유의한 차이는 없었다(Table 3).

8주간의 치료 전과 후를 비교하였을 때, RSI는 양성자 펌프

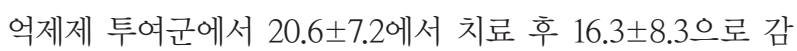
소하였고 통계적으로 유의한 차이가 있었다 $(p=0.002)$. 비투 여군에서도 $20.4 \pm 5.8$ 에서 20.2 \pm 5.6 으로 감소하였으나, 통계 적으로 유의한 차이는 없었다 $(p=0.784)(F i g .1 \mathrm{~A}) . \mathrm{RFS}$ 는 투 여군에서 치료 전 $12.5 \pm 2.9$ 에서 치료 후 $11.2 \pm 3.3$ 으로 감소 하였으며, 통계적으로 유의한 차이를 보였다 $(p<0.001)$. 비투 여군에서 역시 $12.2 \pm 2.6$ 에서 $11.4 \pm 2.2$ 로 감소하여 통계적으 로 유의한 차이가 있었다 $(p=0.019)$ (Fig. 1B). 만성 비부비동 염에 대해 평가한 SNOT-20은 양성자 펌프 억제제 투여군에 서 치료 전 $32.4 \pm 17.3$ 에서 치료 후 $27.6 \pm 17.9$ 로 호전되어 통 계적으로 유의한 차이를 보였고 $(p=0.005)$, 비투여군에서는

Table 3. Characteristics of the each treatment group

\begin{tabular}{lccc}
\hline & PPI negative $(n=72)$ & PPI positive $(n=92)$ & $p$-value \\
\hline Sex (male:female) & $24: 48$ & $30: 62$ & 0.946 \\
Age (years) & 48.3 & 49.2 & 0.754 \\
Initial RSI & $20.4 \pm 5.8$ & $20.6 \pm 7.2$ & 0.896 \\
Initial RFS & $12.2 \pm 2.6$ & $12.5 \pm 2.9$ & 0.568 \\
Initial SNOT-20 & $35.0 \pm 12.6$ & $32.4 \pm 17.3$ & 0.440 \\
Initial Lund-Kennedy score & $4.3 \pm 1.1$ & $4.1 \pm 1.4$ & 0.531 \\
\hline
\end{tabular}

PPI: proton pump inhibitor, RSI: reflux symptom index, RFS: reflux finding score, SNOT-20: Sino-Nasal Outcome Test-20 
$35.0 \pm 12.6$ 에서 $33.9 \pm 9.9$ 로 감소하였으나 통계적으로 유의한 차이는 없었다 $(p=0.374)$ (Fig. 2A). Lund-Kennedy 내시경 점 수는 투여군에서 $4.1 \pm 1.4$ 에서 $3.6 \pm 1.5$ 로 호전되었으며 $(p<$ $0.001)$, 비투여군에서는 $4.3 \pm 1.1$ 에서 $4.4 \pm 0.9$ 로 유의한 차이
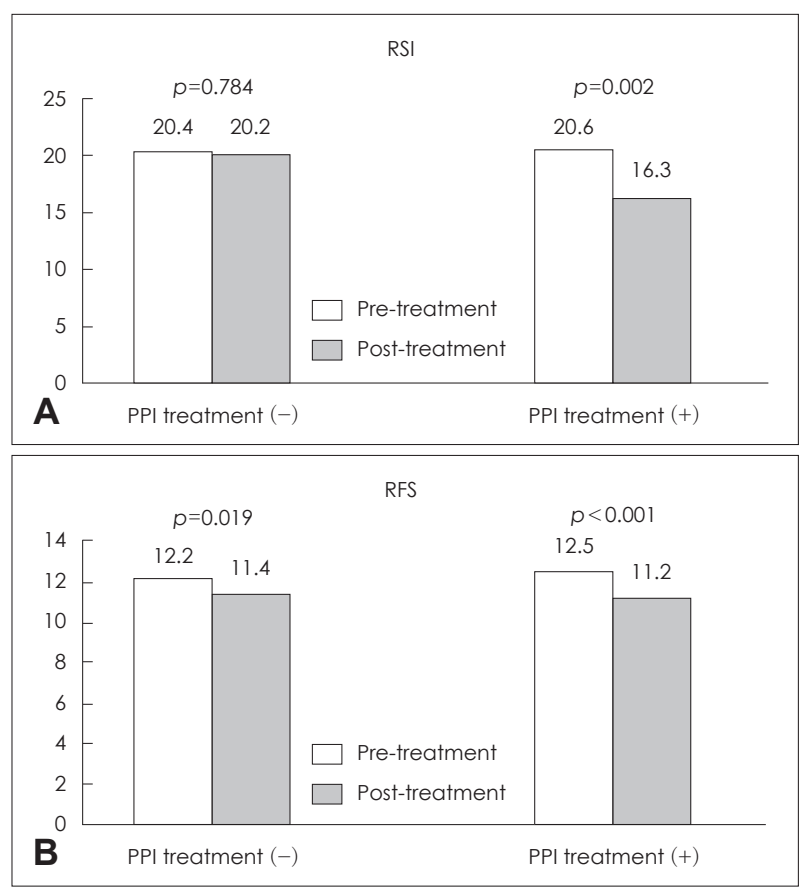

Fig. 1. Pre and post treatment RSI (A) and RFS (B) according to treatment group. PPI: proton-pump inhibitor, RSI: reflux symptom index, RFS: reflux finding score.
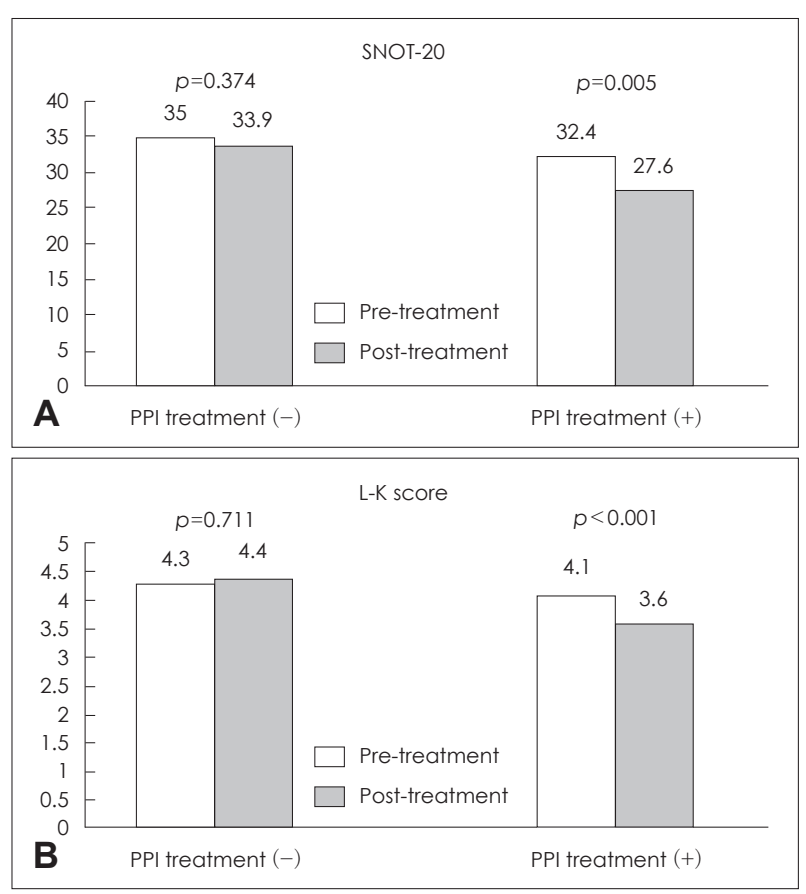

Fig. 2. Pre and post treatment SNOT-20 (A) and L-K (B) endoscopic score according to treatment group. PPI: proton-pump inhibitor, SNOT-20: Sino-Nasal Outcome Test-20, L-K: Lund-Kennedy.
를 보이지 않았다( $p=0.711)$ (Fig. 2B).

\section{고 찰}

인후두 역류증은 매우 흔한 질환이지만, 일상생활에서 신 경성 또는 건강염려증 등으로 간과되거나 잘못된 방법으로 치료하고 있는 경우가 많다. 하지만 최근 인후두 역류증과 다양한 상기도 질환과의 연관성이 밝혀지면서 인후두 역류 증에 대한 이해와 인지의 필요성이 증가하였다. ${ }^{15-17)}$ 최근 연 구에서 인후두 역류증과 만성 비부비동염의 연관성에 대해 보고된 바 있다. ${ }^{18,19)}$ 만성 비부비동염 환자에서 인후두 역류 증이 동반되는 경우가 많다는 보고가 있으며," ${ }^{9}$ Ozmen 등 ${ }^{8}$ 의 연구에서는 수소이온농도지수 측정검사(pH-metry)를 시행하 여 만성 비부비동염 환자의 $88 \%$ 에서 역류를 관찰함으로써 정상 환자의 $55 \%$ 보다 더 높다고 보고한 바 있다. 하지만 만성 비부비동염과 인후두 역류증의 유병률이 둘 다 높기 때문에 두 가지 질병이 독립적으로 존재할 수 있으며, 이러한 이유로 만성 비부비동염과 인후두 역류증의 직접적인 연관성을 밝히 기는 쉽지 않다는 의견도 있다. ${ }^{20}$

인후두 역류증이 어떻게 비부비동 점막의 손상을 일으키는 지에 대한 이해는 아직 부족하다. 인후두 역류증과 만성 비부 비동염의 연관성에 대한 몇몇 가설이 제시된 바 있다. 첫 번째 는 비점막이 역류된 위 내용물에 직접 접촉하게 되면서, 점 막의 염증과 점액섬모 운동의 저하를 유발하여, 그 결과 부비 동 입구의 폐쇄 및 비점막의 반복적인 염증을 유발한다는 이 론이다. ${ }^{21-24)} \mathrm{pH}$ 의 변화가 호흡 점막의 섬모 운동과 형태에 영 향을 미친다는 것은 알려진 바 있으며, ${ }^{25)}$ 위산과 더불어 펩신 이 함께 존재하는 경우에는 점막 손상의 빈도가 증가하게 된 다. ${ }^{26)}$ 두 번째는 자율신경계의 기능 이상으로 부비강 점막의 종창과 염증이 유발되며, 이로 인해 부비동 입구가 막힌다는 가설이다. ${ }^{27,28)} \mathrm{Wong}$ 등 ${ }^{29}$ 은 정상인에서 염산이 하부 식도에 접촉함으로써 비점액의 증가, 비증상 점수의 증가, 최고흡기 유속의 감소를 보고한 바 있다. 마지막 가설은 헬리코박터 파 일로리(Helicobacter pylori, H. pylori)의 직접적인 영향이다. $\mathrm{Koc}$ 등 $^{30}$ 은 비용 조직에서 H. pylori의 존재를 관찰한 바 있 으며, Morinaka 등 ${ }^{31)}$ 의 연구에서는 만성 비부비동염과 인후 두 역류증이 있는 환자의 비점막에서 중합효소 연쇄 반응을 통해 H. pylori를 증명한 바 있다.

인후두 역류증에서 동반된 만성 비부비동염에 대해 양성 자 펌프 억제제 치료에 따른 비증상의 호전 여부를 조사한 연구들이 있다. ${ }^{32,33)}$ 가장 최근에 발표된 Anzic 등 ${ }^{22)}$ 의 연구 는 무작위 이중맹검 위약대조 연구를 통해 인후두 역류증이 동반된 만성 비부비동염 환자 60명에서 오메프라졸 $20 \mathrm{mg}$ 을 
8주간 치료하여 내시경 점수와, 주관적 설문지로 평가한 증상 점수 모두에서 유의한 증상 호전을 보고한 바 있다. DiBaise 등 $^{34}$ 도 만성 비부비동염과 인후두 역류증이 있는 환자들에 서 오메프라졸 $20 \mathrm{mg}$ 을 하루 두 번 12주간 치료하여 비증상 의 호전을 보고한 바 있으며, Pincus 등 ${ }^{35}$ 의 연구에서는 난치 성 만성 비부비동염 환자 30 명 중 25 명에서 인후두 역류증을 증명하였으며, 이들에 대해 양성자 펌프 억제제를 치료하여 15 명 중 14 명에서 비증상의 호전을 보인 바 있다. 본 연구에 서는 8주간의 일라프라졸 $20 \mathrm{mg}$ 치료에 대해서, 만성 비부 비동염에서의 주관적 증상을 평가한 SNOT-20, 그리고 객관 적 내시경 점수인 Lund-Kennedy 내시경 점수에서 모두 유 의한 호전을 보였다. 최근 발표된 메타 분석 논문에서는 12 개의 논문들을 통해 만성 비부비동염, 특히 임상적으로 난치 성의 만성 비부비동염에서 인후두 역류증과의 연관성이 있 다고 분석하였으며, 인후두 역류증에 대한 치료가 만성 비부 비동염 증상 호전에 도움이 되었다고 보고하고 있다. ${ }^{36)}$ 하지 만 포함된 연구의 수가 적고, 약물 종류 및 투약 방법 등이 다 르기에 충분한 근거를 제시하고 있지는 못하다.

본 연구는 위약 투약 대조군의 연구 결과가 없다는 점에서, 약물 치료 이후의 증상 호전이 양성자 펌프 억제제의 효과만 이라고 판단할 수 없는 제한점이 있다. 하지만 본 연구는 만 성 비부비동염과 인후두 역류증에 대해 주관적 증상을 평가 한 설문지뿐만 아니라 객관적인 내시경 소견을 측정함으로써, 양성자 펌프 억제제의 장기 치료가 위약에 대비한 효과는 증 명하지 못하였지만, 만성 비부비동염의 주관적, 객관적 증상 모두를 호전시킨 결과를 보였다는 점에 의의가 있다. 양성자 펌프 억제제의 장기 사용 시 부작용으로 감염(폐렴, 장염), 신장 이상, 골다공증 등이 알려져 있으나, ${ }^{37,38)}$ 본 연구에서 그러한 부작용을 보이는 환자는 없었다. 또한 좀 더 검증된 객관적 검사인 24시간 이중 탐침 산도 검사 등을 통해 인후두 역류 증을 진단하지 않았다는 것에 한계가 있다. 하지만 24시간 이 중 탐침 산도 검사는 침습적이라는 단점이 있다. ${ }^{39)}$ 본 연구에 서는 이에 RSI와 RFS를 인후두 역류증의 진단에 사용하였다. Belafsky 등 ${ }^{10,11,40)}$ 이 인후두 역류로 인한 증상과 후두내시경 소견을 점수화하여 제시한 RSI와 RFS는 인후두 역류 질환 의 진단과 치료 후 추적관찰에 효과적인 방법이며, RSI는 13 이상, RFS는 7 이상이 유의하게 증가된 수치이며 이 자체가 인후두 역류증의 진단 기준은 아니지만 인후두 역류증을 의 심할 수 있다고 인정되고 있다. ${ }^{39,41}$ 2011년 대한이비인후과학 회가 발표한 표준진료지침에도 후두내시경을 시행하여 RFS 가 7점 이상일 때 인후두 역류증을 의심해볼 수 있다고 권고 하고 있다. ${ }^{42)}$

\section{REFERENCES}

1) Koufman JA. Laryngopharyngeal reflux: a new paradigm of airway disease. Ear Nose Throat J 2002;81(9 Suppl 2):2-6.

2) Ford CN. Evaluation and management of laryngopharyngeal reflux. JAMA 2005;294(12):1534-40.

3) Shin KS, Tae K, Jeong JH, Jeong SW, Kim KR, Park CW, et al. The role of psychological distress in laryngopharyngeal reflux patients: a prospective questionnaire study. Clin Otolaryngol 2010;35(1):25-30.

4) Woo JS. Ultra-structural and molecular aspects of laryngopharyngeal reflux. Korean J Otorhinolaryngol-Head Neck Surg 2009;52(5):394400.

5) Bock JM, Poetker DM. Reflux and chronic rhinosinusitis. JAMA Otolaryngol Head Neck Surg 2016;142(7):633-4.

6) Ulualp SO, Toohill RJ, Hoffmann R, Shaker R. Possible relationship of gastroesophagopharyngeal acid reflux with pathogenesis of chronic sinusitis. Am J Rhinol 1999;13(3):197-202.

7) Flook EP, Kumar BN. Is there evidence to link acid reflux with chronic sinusitis or any nasal symptoms? A review of the evidence. Rhinology 2011;49(1):11-6.

8) Ozmen S, Yücel OT, Sinici I, Ozmen OA, Süslü AE, Oğretmenoğlu $\mathrm{O}$, et al. Nasal pepsin assay and $\mathrm{pH}$ monitoring in chronic rhinosinusitis. Laryngoscope 2008;118(5):890-4.

9) Koufman JA, Aviv JE, Casiano RR, Shaw GY. Laryngopharyngeal reflux: position statement of the committee on speech, voice, and swallowing disorders of the American Academy of OtolaryngologyHead and Neck Surgery. Otolaryngol Head Neck Surg 2002;127(1): 32-5.

10) Belafsky PC, Postma GN, Koufman JA. Validity and reliability of the reflux symptom index (RSI). J Voice 2002;16(2):274-7.

11) Belafsky PC, Postma GN, Koufman JA. The validity and reliability of the reflux finding score (RFS). Laryngoscope 2001;111(8):1313-7.

12) Fokkens WJ, Lund VJ, Mullol J, Bachert C, Alobid I, Baroody F, et al. EPOS 2012: European position paper on rhinosinusitis and nasal polyps 2012. A summary for otorhinolaryngologists. Rhinology 2012; 50(1):1-12.

13) Piccirillo JF, Merritt MG Jr, Richards ML. Psychometric and clinimetric validity of the 20-Item Sino-Nasal Outcome Test (SNOT-20). Otolaryngol Head Neck Surg 2002;126(1):41-7.

14) Lund VJ, Kennedy DW. Staging for rhinosinusitis. Otolaryngol Head Neck Surg 1997;117(3 Pt 2):S35-40.

15) Papakonstantinou L, Leslie P, Gray J, Chadwick T, Hudson M, Wilson JA. Laryngopharyngeal reflux: a prospective analysis of a 34 item symptom questionnaire. Clin Otolaryngol 2009;34(5):455-9.

16) Cohen JT, Bach KK, Postma GN, Koufman JA. Clinical manifestations of laryngopharyngeal reflux. Ear Nose Throat J 2002;81(9 Suppl 2): $19-23$.

17) Weaver EM. Association between gastroesophageal reflux and sinusitis, otitis media, and laryngeal malignancy: a systematic review of the evidence. Am J Med 2003;115 Suppl 3A:81S-9S.

18) Katle EJ, Hatlebakk JG, Steinsvåg S. Gastroesophageal reflux and rhinosinusitis. Curr Allergy Asthma Rep 2013;13(2):218-23.

19) DelGaudio JM. Direct nasopharyngeal reflux of gastric acid is a contributing factor in refractory chronic rhinosinusitis. Laryngoscope 2005;115(6):946-57.

20) Wong IW, Omari TI, Myers JC, Rees G, Nair SB, Jamieson GG, et al. Nasopharyngeal $\mathrm{pH}$ monitoring in chronic sinusitis patients using a novel four channel probe. Laryngoscope 2004;114(9):1582-5.

21) Delehaye E, Dore MP, Bozzo C, Mameli L, Delitala G, Meloni F. Correlation between nasal mucociliary clearance time and gastroesophageal reflux disease: our experience on 50 patients. Auris Nasus Larynx 2009;36(2):157-61.

22) Tobey NA, Carson JL, Alkiek RA, Orlando RC. Dilated intercellular spaces: a morphological feature of acid reflux-damaged human esophageal epithelium. Gastroenterology 1996;111(5):1200-5. 
23) Tobey NA, Koves G, Orlando RC. HCl-induced cell edema in primary cultured rabbit esophageal epithelium. Gastroenterology 1997;112(3): 847-54.

24) Orlando RC. Esophageal epithelial defense against acid injury. J Clin Gastroenterol 1991;13 Suppl 2:S1-5.

25) Holma B, Lindegren M, Andersen JM. PH effects on ciliomotility and morphology of respiratory mucosa. Arch Environ Health 1977;32(5): 216-26.

26) Tobey NA, Hoseini SS, Caymaz-Bor C, Wyatt HR, Orlando GS, Orlando RC. The role of pepsin in acid injury to esophageal epithelium. Am J Gastroenterol 2001;96(11):3062-70.

27) Lodi U, Harding SM, Coghlan HC, Guzzo MR, Walker LH. Autonomic regulation in asthmatics with gastroesophageal reflux. Chest 1997; 111(1):65-70.

28) Loehrl TA, Smith TL, Darling RJ, Torrico L, Prieto TE, Shaker R, et al. Autonomic dysfunction, vasomotor rhinitis, and extraesophageal manifestations of gastroesophageal reflux. Otolaryngol Head Neck Surg 2002;126(4):382-7.

29) Wong IW, Rees G, Greiff L, Myers JC, Jamieson GG, Wormald PJ. Gastroesophageal reflux disease and chronic sinusitis: in search of an esophageal-nasal reflex. Am J Rhinol Allergy 2010;24(4):255-9.

30) Koc C, Arikan OK, Atasoy P, Aksoy A. Prevalence of Helicobacter pylori in patients with nasal polyps: a preliminary report. Laryngoscope 2004;114(11):1941-4.

31) Morinaka S, Ichimiya M, Nakamura H. Detection of Helicobacter pylori in nasal and maxillary sinus specimens from patients with chronic sinusitis. Laryngoscope 2003;113(9):1557-63.

32) Anzić SA, Turkalj M, Župan A, Labor M, Plavec D, Baudoin T. Eight weeks of omeprazole $20 \mathrm{mg}$ significantly reduces both laryngopharyngeal reflux and comorbid chronic rhinosinusitis signs and symptoms: randomised, double-blind, placebo-controlled trial. Clin Otolaryngol 2018;43(2):496-501.

33) Vaezi MF, Hagaman DD, Slaughter JC, Tanner SB, Duncavage JA, Allocco CT, et al. Proton pump inhibitor therapy improves symptoms in postnasal drainage. Gastroenterology 2010;139(6):1887-93.e1.

34) DiBaise JK, Olusola BF, Huerter JV, Quigley EM. Role of GERD in chronic resistant sinusitis: a prospective, open label, pilot trial. Am J Gastroenterol 2002;97(4):843-50.

35) Pincus RL, Kim HH, Silvers S, Gold S. A study of the link between gastric reflux and chronic sinusitis in adults. Ear Nose Throat J 2006; 85(3):174-8

36) Sella GCP, Tamashiro E, Anselmo-Lima WT, Valera FCP. Relation between chronic rhinosinusitis and gastroesophageal reflux in adults: systematic review. Braz J Otorhinolaryngol 2017;83(3):356-63.

37) Scarpignato C, Gatta L, Zullo A, Blandizzi C. Effective and safe proton pump inhibitor therapy in acid-related diseases - A position paper addressing benefits and potential harms of acid suppression. BMC Med 2016;14(1):179.

38) Boghossian TA, Rashid FJ, Thompson W, Welch V, Moayyedi P, RojasFernandez C, et al. Deprescribing versus continuation of chronic proton pump inhibitor use in adults. Cochrane Database Syst Rev 2017;3:CD011969.

39) Oh JH, Ji YB, Song CM, Jung JH, Jin BJ, Tae K. Correlation between ambulatory 24 hour dual probe $\mathrm{pH}$ monitoring and reflux finding score, reflux symptom index in the laryngopharyngeal reflux. Korean J Otorhinolaryngol-Head Neck Surg 2013;56(11):706-10.

40) Belafsky PC, Postma GN, Amin MR, Koufman JA. Symptoms and findings of laryngopharyngeal reflux. Ear Nose Throat J 2002;81(9 Suppl 2):10-3.

41) Yoo CS, Kim DS, Lee SK, Lee BD, Chang HS, Kang JW. A study for causative disease of globus pharyngeus patient who have no pathologic conditions in laryngopharynx. Korean J OtorhinolaryngolHead Neck Surg 1998;41(12):1573-8.

42) Lee JH, Shin HA, Choi HS, Kim CY, Jeong SW, Chang JH. Change of voice quality before and after treatment of short-term therapy with proton pump inhibitor in laryngopharyngeal reflux. Korean $\mathrm{J}$ Otorhinolaryngol-Head Neck Surg 2014;57(10):703-6. 